\title{
Article \\ Clinical and Pathological Characteristics of Hyaline-Vascular Type Unicentric Castleman Disease: A 20-Year Retrospective Analysis
}

\author{
Midori Filiz Nishimura ${ }^{1} \mathbb{D}_{\text {, }}$, Yoshito Nishimura ${ }^{2,3}{ }^{\mathbb{D}}$, Asami Nishikori ${ }^{4} \mathbb{D}^{\mathbb{D}}$, Yukina Maekawa $^{4}$, Kanna Maehama ${ }^{4}$, \\ Tadashi Yoshino ${ }^{1}$ and Yasuharu Sato ${ }^{1,4, * \text { D }}$ \\ 1 Department of Pathology, Okayama University Graduate School of Medicine, Dentistry, and Pharmaceutical \\ Sciences, Okayama 700-8558, Japan; p2hq21br@s.okayama-u.ac.jp (M.F.N.); \\ yoshino@md.okayama-u.ac.jp (T.Y.) \\ 2 Department of General Medicine, Okayama University Graduate School of Medicine, Dentistry, \\ and Pharmaceutical Sciences, Okayama 700-8558, Japan; nishimura-yoshito@okayama-u.ac.jp \\ 3 Department of Medicine, John A. Burns School of Medicine, University of Hawai'i, Honolulu, HI 96813, USA \\ 4 Division of Pathophysiology, Okayama University Graduate School of Health Sciences, \\ Okayama 700-8558, Japan; asami.kei@s.okayama-u.ac.jp (A.N.); paky6h76@s.okayama-u.ac.jp (Y.M.); \\ pz4g0ufl@s.okayama-u.ac.jp (K.M.) \\ * Correspondence: satou-y@okayama-u.ac.jp; Tel.: +81-86-235-7150
}

check for updates

Citation: Nishimura, M.F.; Nishimura, Y.; Nishikori, A.;

Maekawa, Y.; Maehama, K.; Yoshino,

T.; Sato, Y. Clinical and Pathological Characteristics of Hyaline-Vascular Type Unicentric Castleman Disease: A 20-Year Retrospective Analysis. Diagnostics 2021, 11, 2008. https:// doi.org/10.3390/diagnostics11112008

Academic Editor: Gaetano Magro

Received: 20 September 2021

Accepted: 25 October 2021

Published: 28 October 2021

Publisher's Note: MDPI stays neutral with regard to jurisdictional claims in published maps and institutional affiliations.

Copyright: (C) 2021 by the authors. Licensee MDPI, Basel, Switzerland. This article is an open access article distributed under the terms and conditions of the Creative Commons Attribution (CC BY) license (https:// creativecommons.org/licenses/by/ $4.0 /)$.

\begin{abstract}
The first case of hyaline vascular type of unicentric Castleman disease (HV-UCD) was reported more than six decades ago. Since patients with HV-UCD are often asymptomatic and this condition is generally discovered incidentally on imaging tests, most of the previous reports were of mediastinal origin detected by chest radiography. In recent years, improved access to imaging modalities has provided new insights in the diagnosis of this condition. In this study, we reviewed the detailed clinical and pathological findings of 38 HV-UCD cases (20 males and 18 females, mean age: 42.8 years). The most common site involved was the abdominal cavity $(34.2 \%)$, followed by mediastinum (23.7\%) and retroperitoneum (15.8\%). In the abdominal cavity, mesenteric origin was the most common. The mean size of masses was $4.8 \mathrm{~cm}$. Pathologically, thick hyalinized collagen fibers surrounding large blood vessels and calcification were observed ( $81.6 \%$ and $23.7 \%$, respectively). Multinucleated giant cells resembling Warthin-Finkeldey cell were also observed in occasional cases $(23.7 \%)$. This is a unique paper that summarizes detailed clinical and pathological findings of a large series of a rare disease. The clinical information presented in this paper is more plausible than previous views and is useful for accurate diagnosis and understanding of the disease.
\end{abstract}

Keywords: Castleman disease; hyaline vascular type; unicentric Castleman disease; abdominal cavity; mediastinum

\section{Introduction}

Castleman disease (CD) is a rare lymphoproliferative disease, consisting of several subtypes. Each subtype of CD has a different etiology, clinical manifestations, and histology. According to the number of enlarged lymph node regions, CD is divided into two major types: unicentric and multicentric. Unicentric CD (UCD) involves only one lymph node area and is often asymptomatic or mildly symptomatic, whereas multicentric CD (MCD) is associated with systemic symptoms and extensive lymph node involvement. UCD is further divided into two subtypes based on their histological characteristics: hyaline vascular (HV) type and plasma cell (PC) type. The HV type is characterized by increased lymphoid follicles with regressed germinal centers, hyalinized vessels, and hypervascularity within the interfollicular area. The PC type is characterized by hyperplastic germinal centers with sheet-like proliferation of plasma cells within the expanded interfollicular area. It has been reported that most cases of UCD are of the HV type (74.4-91.4\%) [1-4]. 
CD was first reported in 1954 by Castleman et al. as a case of a 40-year-old man with a large mediastinal mass which turned out to be lymph node hyperplasia revealing follicles with hyalinized foci [5]. Subsequently, Castleman reported a series of 13 patients with enlarged mediastinal lymph nodes having histological features that were similar to those of currently defined HV-UCD [6]. HV-UCD is considered to be a histologically and clinically homogeneous entity, lacking systemic symptoms, and is usually curable with excision of local lesions. Keller and Castleman et al. reported that the most commonly affected sites in HV-UCD were the mediastinum and lung hilum (90.5\%), neck (6.8\%), retroperitoneum $(1.4 \%)$, axilla (1.4\%), and pelvis (1.4\%) [1]. In the years when Castleman and Keller reported the disease, chest radiography was the main diagnostic modality, so the percentages of mediastinum and lung hilum lesions may have been higher than they actually were.

UCD can occur at any age and occurs equally in men and women, with a mean age at presentation of approximately 33.8-46.0 years [3,7-10]. In a systematic review of 235 cases of UCD it was found that the most common sites of involvement included the chest $(28.9 \%)$, neck $(23.4 \%)$, abdomen $(20.9 \%)$, and retroperitoneum $(16.6 \%)$ [8]. However, the included data in this review were from different periods and countries and may differ from the actual data. Another article, which was a case series, reported that in 43 patients with UCD (32 HV-CD and 11 PC-CD), the sites found to be commonly involved, in decreasing order of frequency, were the abdomen (39.5\%), neck (23.3\%), mediastinum $(16.3 \%)$, and lung hilum $(7.0 \%)$, with limited involvement of lymph nodes in the axilla and groin [4]. There are no studies to date that have exclusively reported data on HV-UCD. Thus, in the present study we have carried out a detailed clinical and pathological evaluation of 38 cases of HV-UCD and presented a comprehensive description of the obtained findings.

\section{Materials and Methods}

\subsection{Patient Selection}

The study protocol was approved by the Institutional Review Board of Okayama University, Okayama, Japan. We used opt-out to obtain consent for participation in this study. A total of 38 Japanese patients with HV-UCD were retrospectively identified and included in this study. All cases were retrieved from surgical pathology consultation files from the Department of Pathology of Okayama university between the years 2001-2020. In all cases, the lesions were localized in a single region. Immunostaining for CD20, CD3 and $\mathrm{Ki}-67$ was performed in all these patients, and lymphoma was ruled out. Human herpes virus type 8 infectious status was not examined in this study population. None of the patients had autoimmune diseases or used corticosteroids or immunosuppressants. Other diseases with histopathological features overlapping with those of UCD were also excluded according to the guidelines of Frits et al. [11]. All the included patients had undergone surgery for total resection of the lesion.

\subsection{Diagnosis of $H V$-UCD}

The diagnosis of HV-UCD was made in postoperative surgical specimens and diagnosed by several pathologists at the department of pathology case review meeting. The pathological diagnosis of CD was established according to Keller's criteria [1]. All cases satisfied the following histologic criteria: (1) proliferation of follicle-like structures, (2) regressed germinal center with radially penetrating capillaries, (3) extensive capillary proliferation with obliteration of lymphatic sinuses, and (4) perivascular hyalinization in both the germinal center and interfollicular area.

\section{Results}

\subsection{Clinical Findings}

The demographic and clinical characteristics of HV UCD patients are summarized in Tables 1 and 2 provides detailed clinical information for all cases. 
Table 1. Demographic and Clinical Features of Patients with HV-type UCD.

\begin{tabular}{|c|c|}
\hline & $\mathrm{n}=38$ \\
\hline \multicolumn{2}{|l|}{ Age (year) } \\
\hline mean $\pm \mathrm{SD}$ (range) & $42.8 \pm 17.8(12-76)$ \\
\hline$<50, \mathrm{n}(\%)$ & $24(63.2)$ \\
\hline$\geq 50, \mathrm{n}(\%)$ & $14(36.8)$ \\
\hline $\operatorname{Sex}(\mathrm{M}: \mathrm{F})$ & $20: 18$ \\
\hline \multicolumn{2}{|l|}{ Symptom, n (\%) } \\
\hline None & $27(71.1)$ \\
\hline Local pain & $2(5.3)$ \\
\hline Awareness of the mass & $7(18.4)$ \\
\hline Abdominal discomfort & $1(2.6)$ \\
\hline Paraneoplastic pemphigus & $1(2.6)$ \\
\hline \multicolumn{2}{|l|}{ Site, n (\%) } \\
\hline Abdominal cavity & $13(34.2)$ \\
\hline Mesentery & $7(18.4)$ \\
\hline Omentum & $2(5.3)$ \\
\hline Lesser omentum & $1(2.6)$ \\
\hline Abdominal wall & $1(2.6)$ \\
\hline Pelvis & $2(5.3)$ \\
\hline Mediastinum & $9(23.7)$ \\
\hline Posterior & $4(10.5)$ \\
\hline Anterior & $2(5.3)$ \\
\hline Superior & $2(5.3)$ \\
\hline Middle & $1(2.6)$ \\
\hline Retroperitoneum & $6(15.8)$ \\
\hline Lymph node & $5(13.2)$ \\
\hline Axillary Lymph node & $2(5.3)$ \\
\hline Cervical Lymph node & $2(5.3)$ \\
\hline Hilar Lymph node & $1(2.6)$ \\
\hline Soft tissue & $4(10.5)$ \\
\hline Kidney & $1(2.6)$ \\
\hline \multicolumn{2}{|c|}{ Tumor diameter $(\mathrm{cm})$ mean $\pm \mathrm{SD}$ (range) } \\
\hline Total & $4.8 \pm 2.2(1.7-11.0)$ \\
\hline Abdominal & $4.1 \pm 1.4(2.0-6.5)$ \\
\hline Retroperitoneum & $5.8 \pm 3.0(3.0-11.0)$ \\
\hline Mediastinum & $4.8 \pm 2.3(1.7-9.0)$ \\
\hline Soft tissue & $4.3 \pm 1.2(3.0-5.0)$ \\
\hline \multicolumn{2}{|l|}{ Laboratory findings (mean \pm SD) } \\
\hline $\mathrm{WBC}(/ \mu \mathrm{L})(\mathrm{n}=22)$ & $5467 \pm 1663$ \\
\hline $\mathrm{Hb}(\mathrm{g} / \mathrm{dL})$ male $(\mathrm{n}=13)$ & $15.0 \pm 1.0$ \\
\hline $\mathrm{Hb}(\mathrm{g} / \mathrm{dL})$ female $(\mathrm{n}=9)$ & $13.4 \pm 1.4$ \\
\hline $\operatorname{Plt}\left(\times 10^{4} / \mu \mathrm{L}\right)(\mathrm{n}=22)$ & $26.8 \pm 7.1$ \\
\hline $\mathrm{TP}(\mathrm{g} / \mathrm{dL})(\mathrm{n}=21)$ & $7.3 \pm 0.4$ \\
\hline $\operatorname{Alb}(\mathrm{g} / \mathrm{dL})(\mathrm{n}=21)$ & $4.4 \pm 0.5$ \\
\hline $\mathrm{CRP}(\mathrm{mg} / \mathrm{dL})(\mathrm{n}=20)$ & $0.2 \pm 0.2$ \\
\hline $\mathrm{LDH}(\mathrm{U} / \mathrm{L})(\mathrm{n}=22)$ & $184 \pm 53.5$ \\
\hline
\end{tabular}

Abbreviations: SD; standard deviation, WBC; white blood cell, Hb: hemoglobin, Plt; platelet, TP; Total protein, Alb; albumin, CRP; C-reactive protein, LDH; Lactate Dehydrogenase. Normal ranges: WBC 3900-9800/ $\mu \mathrm{L}$, $\mathrm{Hb} 13.4-17.6 \mathrm{~g} / \mathrm{dL}$ (male) 11.3-15.2 g/dL (female), Plt 12.7-35.6 × 104/ $\mu \mathrm{L}, \mathrm{TP} 6.7-8.3 \mathrm{~g} / \mathrm{dL}$, Alb 3.7-5.2 g/dL, CRP 0.00-0.30 mg/dl, LDH 119-229 U/L. 
Table 2. Detailed of clinical findings.

\begin{tabular}{|c|c|c|c|c|c|c|c|c|}
\hline Case & Age & Sex & $\begin{array}{c}\text { PMH and } \\
\text { Comorbidities }\end{array}$ & Site & Symptoms & Modality & $\begin{array}{l}\text { Tumor } \\
\text { Diameter } \\
\text { (cm) }\end{array}$ & $\begin{array}{l}\text { Preoperative } \\
\text { Diagnosis }\end{array}$ \\
\hline 1 & 29 & M & None & Retroperitoneum & None & $\begin{array}{l}\text { Lumbar X-ray for } \\
\text { lumbar sprain }\end{array}$ & 3.6 & - \\
\hline 2 & 53 & M & $\begin{array}{c}\text { Colonic } \\
\text { diverticulitis }\end{array}$ & $\begin{array}{l}\text { Abdominal mass } \\
\text { (mesoduodenum) }\end{array}$ & None & $\begin{array}{l}\text { Abdominal US for } \\
\text { diverticulitis }\end{array}$ & 3.0 & - \\
\hline 3 & 61 & $\mathrm{~F}$ & $\begin{array}{l}\text { Hypothyroidism, } \\
\text { Hyperlipidemia }\end{array}$ & Retroperitoneum & None & $\begin{array}{l}\text { Abdominal CT for } \\
\text { hematuria }\end{array}$ & 4.1 & $\begin{array}{l}\text { UCD, paraganglioma, } \\
\text { Liposarcoma, } \\
\text { Leiomyosarcoma }\end{array}$ \\
\hline 4 & 47 & M & Ischemic enteritis & $\begin{array}{l}\text { Abdominal mass } \\
\text { (mesoduodenum) }\end{array}$ & None & $\begin{array}{l}\text { Abdominal CT for } \\
\text { ischemic enteritis }\end{array}$ & 2.0 & $\begin{array}{l}\text { GIST, Leiomyoma, } \\
\text { Neurogenic tumor, } \\
\text { SFT }\end{array}$ \\
\hline 5 & 38 & F & None & $\begin{array}{l}\text { Mediastinum } \\
\text { (middle) }\end{array}$ & None & $\begin{array}{l}\text { CT for high serum } \\
\text { SCC antigen }\end{array}$ & 6.0 & Teratoma, Thymoma \\
\hline 6 & 39 & M & None & $\begin{array}{l}\text { Abdominal mass } \\
\text { (pelvis) }\end{array}$ & Back pain & CT for back pain & 5.0 & - \\
\hline 7 & 36 & M & $\begin{array}{c}\text { Hyperlipidemia, } \\
\text { Chronic gastritis, } \\
\text { Asthma }\end{array}$ & $\begin{array}{l}\text { Abdominal mass } \\
\text { (mesojejunum) }\end{array}$ & None & $\begin{array}{l}\text { Abdominal US for } \\
\text { mild liver } \\
\text { dysfunction }\end{array}$ & 6.5 & $\begin{array}{l}\text { GIST, Neurogenic } \\
\text { tumor, UCD }\end{array}$ \\
\hline 8 & 28 & M & $\begin{array}{l}\text { Type } 2 \text { DM, } \\
\text { Asthma }\end{array}$ & $\begin{array}{l}\text { Mediastinum } \\
\quad \text { (anterior) }\end{array}$ & None & $\begin{array}{l}\text { Screening chest } \\
\text { X-ray }\end{array}$ & 9.0 & $\begin{array}{l}\text { Thymoma, Thymic } \\
\text { carcinoma, } \\
\text { Embryonal tumor }\end{array}$ \\
\hline 9 & 16 & M & None & $\begin{array}{l}\text { Mediastinum } \\
\text { (posterior) }\end{array}$ & None & $\begin{array}{l}\text { School screening } \\
\text { chest X-ray }\end{array}$ & 5.0 & - \\
\hline 10 & 58 & M & $\begin{array}{c}\text { Rectal cancer } \\
\text { (post-therapeutic } \\
\text { state) }\end{array}$ & $\begin{array}{l}\text { Abdominal mass } \\
\text { (transverse } \\
\text { mesocolon) }\end{array}$ & None & $\begin{array}{l}\text { Follow-up CT for } \\
\text { rectal cancer }\end{array}$ & 2.5 & Cancer dissemination \\
\hline 11 & 74 & M & $\begin{array}{c}\text { Post } \\
\text { cholecystectomy }\end{array}$ & $\begin{array}{l}\text { Mediastinum } \\
\text { (anterior) }\end{array}$ & None & $\begin{array}{l}\text { CT for transient } \\
\text { loss of } \\
\text { consciousness }\end{array}$ & 2.6 & Thymoma \\
\hline 12 & 15 & M & None & $\begin{array}{l}\text { Mediastinum } \\
\text { (superior) }\end{array}$ & None & $\begin{array}{l}\text { School screening } \\
\text { chest X-ray }\end{array}$ & 5.0 & $\begin{array}{l}\mathrm{UCD} \text {, neurogenic } \\
\text { tumor }\end{array}$ \\
\hline 13 & 12 & $\mathrm{~F}$ & None & $\begin{array}{l}\text { Soft tissue of } \\
\text { buttocks } \\
\text { (subcutaneous) }\end{array}$ & $\begin{array}{c}\text { Subcutaneous } \\
\text { mass, } \\
\text { Local pain }\end{array}$ & $\begin{array}{c}\text { MRI for } \\
\text { subcutaneous mass }\end{array}$ & 5.0 & $\begin{array}{l}\text { Chronic expanding } \\
\text { hematoma }\end{array}$ \\
\hline 14 & 39 & $\mathrm{~F}$ & None & $\begin{array}{l}\text { Abdominal mass } \\
\text { (omentum) }\end{array}$ & None & $\begin{array}{l}\text { Abdominal US for } \\
\text { regular checkup }\end{array}$ & 5.0 & UCD \\
\hline 15 & 50 & $\mathrm{~F}$ & $\begin{array}{c}\text { Post splenectomy } \\
\text { and } \\
\text { cholecystectomy }\end{array}$ & Retroperitoneum & $\begin{array}{l}\text { Abdominal } \\
\text { discomfort } \\
\text { for the past } \\
\text { two years }\end{array}$ & $\begin{array}{l}\text { Abdominal CT for } \\
\text { abdominal } \\
\text { discomfort }\end{array}$ & 7.6 & $\begin{array}{c}\text { Lymphoma, Sarcoma, } \\
\text { UCD }\end{array}$ \\
\hline 16 & 28 & $\mathrm{~F}$ & $\begin{array}{c}\text { Mediastinal } \\
\text { teratoma } \\
\text { (post-operative } \\
\text { state) }\end{array}$ & Retroperitoneum & None & $\begin{array}{l}\text { Abdominal US for } \\
\text { transient fever }\end{array}$ & 11.0 & - \\
\hline 17 & 76 & F & None & Retroperitoneum & None & $\begin{array}{l}\text { Abdominal US for } \\
\text { regular checkup }\end{array}$ & 3.0 & UCD, Paraganglioma \\
\hline 18 & 23 & $\mathrm{~F}$ & $\begin{array}{c}\text { Amenorrhea } \\
\text { (under hormonal } \\
\text { therapy) }\end{array}$ & $\begin{array}{l}\text { Abdominal } \\
\text { (sigmoid } \\
\text { mesocolon) }\end{array}$ & None & $\begin{array}{l}\text { Abdominal US for } \\
\text { amenorrhea }\end{array}$ & 5.0 & Lymphoma, Sarcoma \\
\hline 19 & 31 & M & None & Axillary LN & $\begin{array}{l}\text { LN swelling } \\
\text { for the past } \\
10 \text { years }\end{array}$ & $\begin{array}{l}\text { CT for thorough } \\
\text { medical checkup }\end{array}$ & 3.6 & $\begin{array}{c}\text { Reactive } \\
\text { lymphadenopathy }\end{array}$ \\
\hline 20 & 45 & $\mathrm{~F}$ & $\begin{array}{c}\text { Uterine } \\
\text { leiomyoma, } \\
\text { Ovarian benign } \\
\text { serous tumor }\end{array}$ & $\begin{array}{l}\text { Abdominal mass } \\
\text { (mesoileum) }\end{array}$ & None & $\begin{array}{l}\text { Abdominal CT for } \\
\text { ovarian lesion }\end{array}$ & 4.5 & GIST \\
\hline 21 & 63 & $\mathrm{~F}$ & $\begin{array}{c}\text { Endometrial } \\
\text { carcinoma } \\
\text { (post-operative } \\
\text { state) }\end{array}$ & $\begin{array}{l}\text { Mediastinum } \\
\text { (posterior) }\end{array}$ & None & $\begin{array}{l}\text { Follow-up CT for } \\
\text { endometrial } \\
\text { carcinoma }\end{array}$ & 1.7 & $\mathrm{UCD}$ \\
\hline
\end{tabular}


Table 2. Cont

\begin{tabular}{|c|c|c|c|c|c|c|c|c|}
\hline Case & Age & Sex & $\begin{array}{c}\text { PMH and } \\
\text { Comorbidities }\end{array}$ & Site & Symptoms & Modality & $\begin{array}{l}\text { Tumor } \\
\text { Diameter } \\
\text { (cm) }\end{array}$ & $\begin{array}{l}\text { Preoperative } \\
\text { Diagnosis }\end{array}$ \\
\hline 22 & 47 & M & None & $\begin{array}{l}\text { Mediastinum } \\
\text { (posterior) }\end{array}$ & None & $\begin{array}{l}\text { CT for thorough } \\
\text { medical checkup }\end{array}$ & 6.5 & $\begin{array}{l}\mathrm{UCD} \text {, neurogenic } \\
\text { tumor }\end{array}$ \\
\hline 23 & 52 & M & None & Axillary LN & $\begin{array}{l}\text { LN swelling } \\
\text { for the past } \\
\text { three years }\end{array}$ & CT for LN swelling & 7.7 & Lymphoma \\
\hline 24 & 69 & $\mathrm{~F}$ & None & $\begin{array}{l}\text { Kidney } \\
\text { (inferior pole of } \\
\text { right kidney) }\end{array}$ & None & $\begin{array}{l}\text { CT for thorough } \\
\text { medical checkup }\end{array}$ & 2.0 & $\begin{array}{l}\text { RCC, Leiomyoma, } \\
\text { Angiomyolipoma }\end{array}$ \\
\hline 25 & 75 & $\mathrm{~F}$ & $\begin{array}{l}\text { Hyperlipidemia, } \\
\text { Arteriosclerosis }\end{array}$ & $\begin{array}{l}\text { Abdominal mass } \\
\text { (abdominal wall) }\end{array}$ & None & $\begin{array}{l}\text { Screening CT for } \\
\text { coronary } \\
\text { arteriosclerosis }\end{array}$ & 2.3 & UCD, NET, GIST, SFT \\
\hline 26 & 46 & M & None & $\begin{array}{c}\text { Soft tissue of } \\
\text { back } \\
\text { (subcutaneous) }\end{array}$ & $\begin{array}{l}\text { Subcutaneous } \\
\text { mass for the } \\
\text { past } 20 \text { years }\end{array}$ & $\begin{array}{c}\mathrm{CT} \text { and MRI for } \\
\text { subcutaneous mass }\end{array}$ & 4,0 & Sarcoma \\
\hline 27 & 20 & $\mathrm{~F}$ & None & $\begin{array}{l}\text { Mediastinum } \\
\text { (superior) }\end{array}$ & None & $\begin{array}{l}\text { Screening chest } \\
\text { X-ray }\end{array}$ & 4.8 & $\begin{array}{l}\text { UCD, Lymphoma, } \\
\text { Neurogenic tumor }\end{array}$ \\
\hline 28 & 48 & $\mathrm{~F}$ & $\begin{array}{l}\text { Uterine } \\
\text { leiomyoma }\end{array}$ & $\begin{array}{l}\text { Abdominal mass } \\
\text { (sigmoid } \\
\text { mesocolon) }\end{array}$ & None & $\begin{array}{l}\text { Abdominal CT for } \\
\text { genital bleeding }\end{array}$ & 3.4 & UCD \\
\hline 29 & 53 & M & None & $\begin{array}{l}\text { Abdominal } \\
\text { (omentum) }\end{array}$ & None & $\begin{array}{l}\text { CT for thorough } \\
\text { medical checkup }\end{array}$ & 5.8 & - \\
\hline 30 & 20 & M & None & Retroperitoneum & PNP, BO & Screening CT & 5.6 & UCD \\
\hline 31 & 38 & $\mathrm{~F}$ & $\begin{array}{c}\text { Uterine } \\
\text { leiomyoma, } \\
\text { Para fallopian } \\
\text { tube cyst }\end{array}$ & $\begin{array}{l}\text { Abdominal mass } \\
\text { (pelvis) }\end{array}$ & None & $\begin{array}{l}\text { Abdominal CT for } \\
\text { genital bleeding }\end{array}$ & 4.0 & - \\
\hline 32 & 38 & M & None & $\begin{array}{l}\text { Abdominal mass } \\
\text { (lesser omentum) }\end{array}$ & None & $\begin{array}{l}\text { Abdominal US for } \\
\text { mild liver } \\
\text { dysfunction }\end{array}$ & 4.0 & - \\
\hline 33 & 53 & $\mathrm{~F}$ & None & Cervical LN & $\begin{array}{l}\text { LN swelling } \\
\text { for the past } \\
10 \text { years }\end{array}$ & CT for LN swelling & 6.3 & $\begin{array}{c}\text { Reactive } \\
\text { lymphadenopathy, } \\
\text { Lymphoma }\end{array}$ \\
\hline 34 & 14 & M & None & $\begin{array}{l}\text { Soft tissue of left } \\
\text { upper arm } \\
\text { (subcutaneous) }\end{array}$ & $\begin{array}{l}\text { Subcutaneous } \\
\text { mass }\end{array}$ & $\begin{array}{c}\text { MRI for } \\
\text { subcutaneous mass }\end{array}$ & 3.0 & Soft tissue tumor \\
\hline 35 & 52 & $\mathrm{~F}$ & None & $\begin{array}{l}\text { Soft tissue of } \\
\text { right upper arm } \\
\text { (subcutaneous) }\end{array}$ & $\begin{array}{l}\text { Subcutaneous } \\
\text { mass }\end{array}$ & $\begin{array}{c}\text { MRI for } \\
\text { subcutaneous mass }\end{array}$ & 5.0 & - \\
\hline 36 & 47 & $\mathrm{M}$ & None & $\begin{array}{l}\text { Mediastinum } \\
\text { (posterior) }\end{array}$ & None & $\begin{array}{l}\text { CT for thorough } \\
\text { medical checkup }\end{array}$ & 2.6 & $\begin{array}{l}\text { GIST, Neurogenic } \\
\text { tumor }\end{array}$ \\
\hline 37 & 28 & $\mathrm{M}$ & None & Hilum LN & None & $\begin{array}{l}\text { Screening chest } \\
\text { X-ray }\end{array}$ & 3.6 & $\begin{array}{l}\text { UCD, SFT, } \\
\text { Carcinoid tumor }\end{array}$ \\
\hline 38 & 65 & F & None & Cervical LN & None & $\begin{array}{l}\text { CT for thorough } \\
\text { medical checkup }\end{array}$ & 1.6 & $\begin{array}{l}\text { IgG4-related disease, } \\
\text { Lymphoma }\end{array}$ \\
\hline
\end{tabular}

Abbreviations: PMH; past medical history, DM; diabetes mellitus, LN; lymph node, SCC; squamous cell carcinoma, US; ultrasonography, CT; computed tomography, MRI; magnetic resonance imaging, UCD; unicentric Castleman disease, GIST; gastrointestinal tumor, SFT; solitary fibrous tumor, RCC; renal cell carcinoma, NET; neuroendocrine tumor, PNP; paraneoplastic pemphigus, BO; bronchiolitis obliterans.

Of the 38 included patients, 20 were men and 18 were women with a mean age of 42.8 years (range, $12-76$ years) at the time of diagnosis. Majority $(24 / 38,63.2 \%)$ of the patients were aged $<50$ years. Comorbidities included hyperlipidemia $(3 / 38,7.9 \%)$, asthma $(2 / 38,5.3 \%)$, and type 2 diabetes mellitus $(1 / 38,2.6 \%)$, as well as a history of malignant or infectious diseases that led to implementation of imaging studies for the diagnosis.

Patients who presented with subcutaneous masses or superficial lymph node swellings were aware of the mass or had localized pain, while most patients with lesions involving the deeper sites were asymptomatic. However, a few patients with retroperitoneal or pelvic masses complained of abdominal discomfort or back pain (2/38, 5.3\%). Notably, in one case, the presence of paraneoplastic pemphigus led to the discovery of a lymph node lesion. The patient had oral erosions for two years prior to the diagnosis of HV-UCD. Subsequently, 
shortness of breath and coughing appeared. After a thorough examination, the patient was diagnosed with paraneoplastic pemphigus (PNP) and bronchiolitis obliterans (BO). Plasmapheresis and oral corticosteroids in a dose of $0.5 \mathrm{mg} / \mathrm{kg}$ were started along with resection of the lesion of HV-UCD, resulting in improvement of mucosal symptoms. The mucosal symptoms relapsed once during the tapering of steroids, but the PNP has been in remission since then with the maintenance dose of oral corticosteroids monotherapy $(0.1 \mathrm{mg} / \mathrm{kg})$. The $\mathrm{BO}$ has yet to go into remission but is well controlled with oral corticosteroids and has not had rapid exacerbations. The patient is still alive 20 years after the diagnosis of HV-UCD.

In 13 patients, lesions were incidentally found during diagnostic investigations for other comorbidities such as malignancy, gynecologic disease, or infection $(13 / 38,34.2 \%)$, whereas some cases were discovered as incidental findings during routine checkups $(9 / 38,23.7 \%)$.

The most common site of involvement was the abdominal cavity $(13 / 38,34.2 \%)$, with lesions of mostly mesenteric origin $(7 / 13)$. This was followed by mediastinum $(9 / 38$, $23.7 \%)$, retroperitoneum $(6 / 38,15.8 \%)$, subcutaneous tissues of the back, buttocks, or extremities $(4 / 38,10.5 \%)$, axillary lymph nodes $(2 / 38,5.3 \%)$, cervical lymph nodes $(2 / 38$, $5.3 \%)$, hilar lymph nodes $(1 / 28,2.6 \%)$, and kidney $(2.6 \%)$. The kidney mass was found within the parenchyma of the lower pole.

${ }^{18} \mathrm{~F}$-fluorodeoxyglucose positron emission tomography-computed tomography $\left({ }^{18} \mathrm{~F}-\right.$ FDG PET-CT) results could be obtained for the following seven patients: patient number $2,7,8,25,27,28,37$. The mean maximum standardized uptake value (SUV-max) was 4.8 (range 2.5-9.1). In all these patients, the identical lesions that had ${ }^{18} \mathrm{~F}-\mathrm{FDG}$ accumulation were surgically resected. There were no other sites showing ${ }^{18} \mathrm{~F}-\mathrm{FDG}$ accumulation other than the resected lesions.

Preoperative differential diagnoses besides HV-UCD included gastrointestinal stromal tumor, solitary fibrous tumor, neurogenic tumor, lymphoma, metastatic carcinoma, and sarcoma in the abdominal cavity; paraganglioma, lymphoma, and sarcoma, in the retroperitoneum; thymoma, thymic carcinoma, neurogenic tumor, embryonal carcinoma, teratoma, and lymphoma, in the mediastinum.

The mean maximum diameter of the evaluated masses was $4.8 \mathrm{~cm}$ (range $1.7-11.0 \mathrm{~cm}$ ). The mean diameters of the lesions in the abdominal cavity, retroperitoneum, and mediastinum were $4.1 \mathrm{~cm}$ (range 2.0-6.5), $5.8 \mathrm{~cm}$ (range 3.0-11.0), and $4.8 \mathrm{~cm}$ (range 1.7-9.0), respectively. All patients underwent total resection of the lesions, and none of them received chemotherapy or radiotherapy. Clinical follow-up was carried out in 17 cases, and no recurrences were reported. The mean follow-up period was 72.7 months. There were no abnormal hematological findings such as anemia, increased inflammatory markers, or hypergammaglobulinemia in any of the patients.

\subsection{Histological Findings}

Representative histological findings of the included cases are presented in Figure 1. HV-UCD is characterized by one or more atrophic germinal centers with small lymphocytes present concentrically around them. Radially penetrating capillaries or branched hyalinized vessels are often observed in atrophic germinal centers. In the interfollicular area, extensive capillary proliferation was observed. Plasmacytes and eosinophils were found sporadically, and no aggregation or sheet-like proliferation of plasma cells was observed. Altered follicle structure with expanded mantle zone (progressive transformation of germinal center-like pattern) was observed in four cases (Figure 2). 


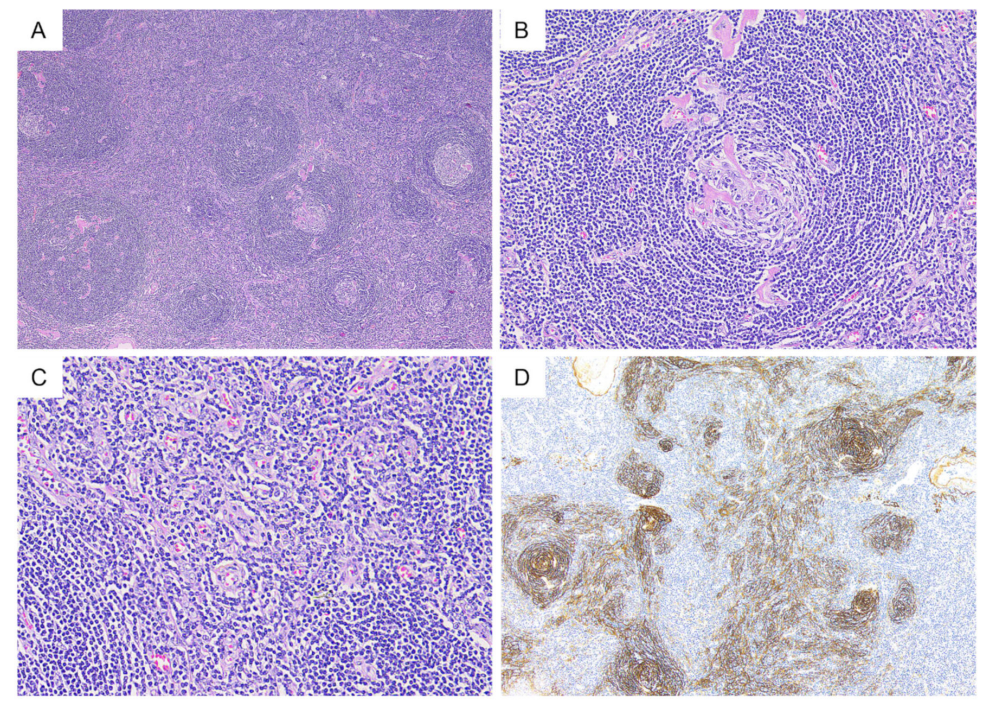

Figure 1. Representative histological findings in hyaline vascular type unicentric Castleman disease. (A) (H\&E); hyperplasia of follicular structures. (B) (H\&E); atrophic germinal center with penetrating hyalinized blood vessels and concentric mantle zones, which is a so-called "lollipop" appearance. (C) (H\&E); extensive capillary proliferation in the interfollicular area was also observed. (D) (CD21); CD21 staining highlights prominent follicular dendritic cell meshwork.
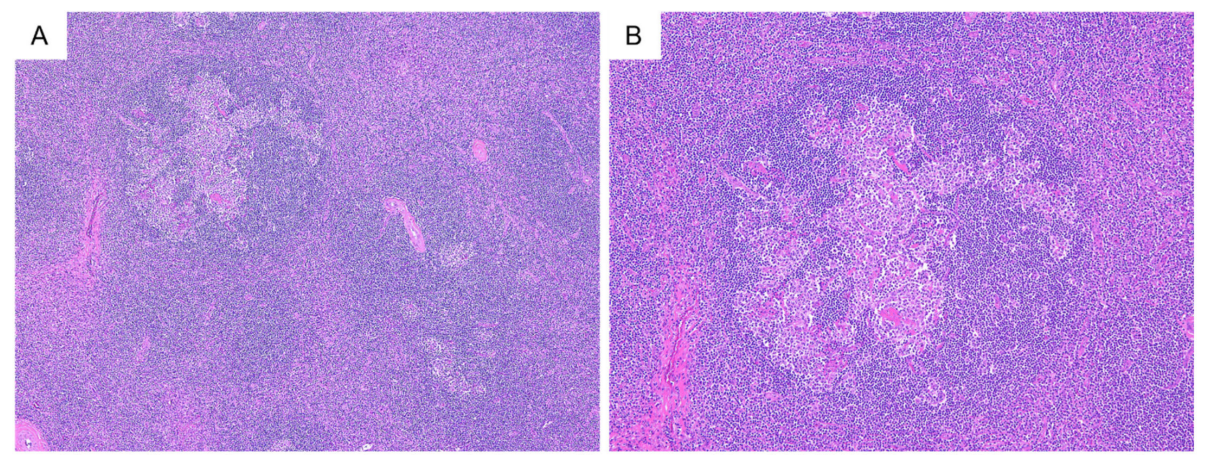

Figure 2. Progressive transformation of germinal centers-like structure. (A,B) (H\&E); altered follicle structures with expanded mantle zones are shown.

The degree of hyalinization was variable. Thick hyalinized collagen fibers were seen in the interfollicular area surrounding large blood vessels while broad hyalinized collagen fibers spreading throughout the lesion were also often observed $(31 / 38,81.6 \%$ and $15 / 38$, $39.5 \%$, respectively) (Figure 3). This broad hyalinized area was associated with calcification in nine patients $(23.7 \%)$.

In the follicular and interfollicular area, multinucleated giant cells resembling WarthinFinkeldey cell were observed in occasional cases (9/38, 23.7\%) (Figure 4). These multinucleated giant cells were observed in the germinal center and interfollicular area. These multinucleated cells were positive for CD21 and CXCL13 in the cytoplasm, and negative for CD23, CD20, CD3, CD43, CD30, and CD68. In CD21 staining, the cytoplasmic border was indistinct, and the cells appeared to trap the surrounding small lymphocytes. These small lymphocytes surrounding the multinucleated cell were negative for CD43 and positive for CD20, suggesting B cells. 

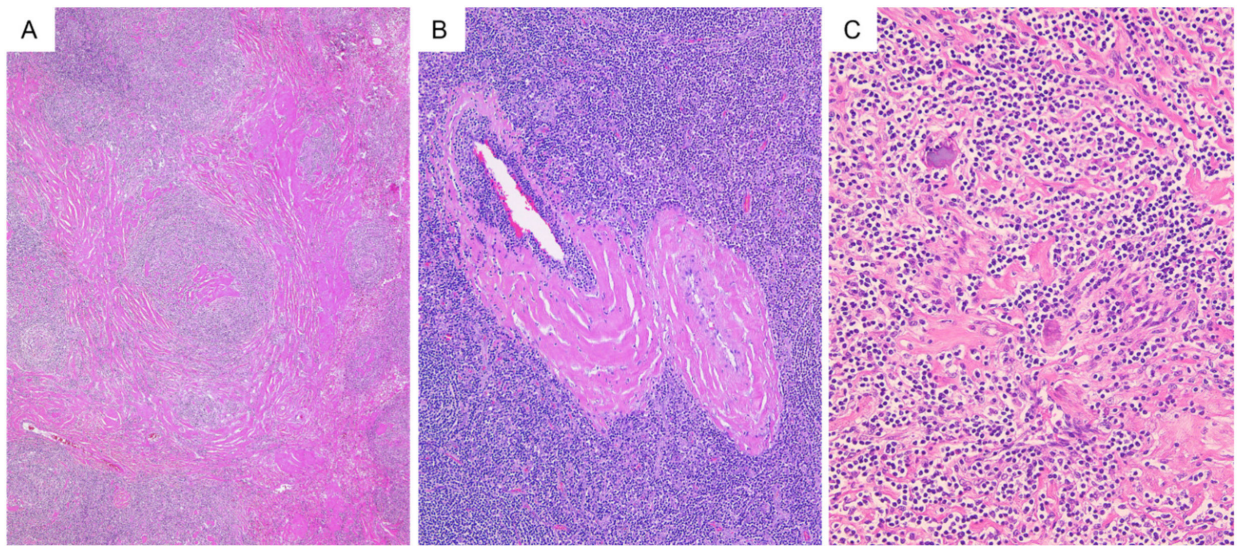

Figure 3. Hyalinization and calcification in hyaline vascular type unicentric Castleman disease. (A) (H\&E); broad hyalinized collagen fibers spreading throughout the lesion. (B) (H\&E); thick hyalinized collagen fibers surrounding large blood vessels. (C) (H\&E); calcium deposition in hyalinized area.

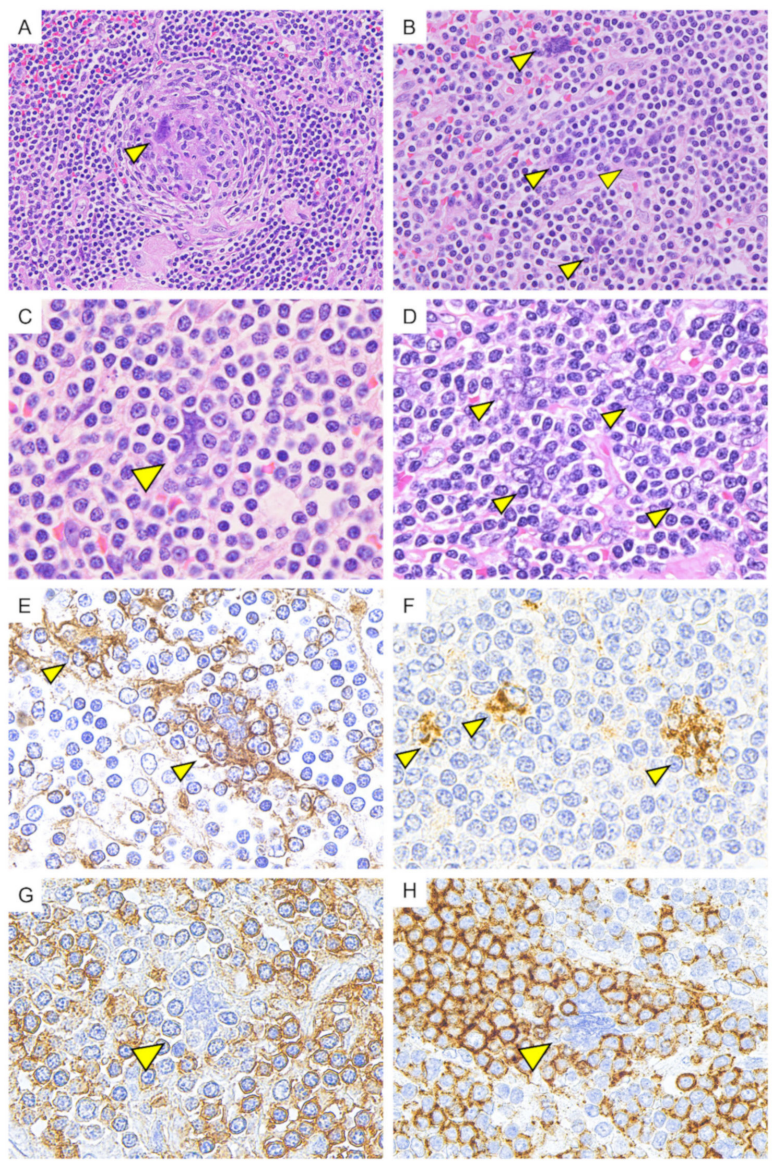

Figure 4. Multinucleated giant cells resembling Warthin-Finkeldey cell (indicated by an arrowhead). (A,B) (H\&E); Multinucleated giant cells resembling Warthin-Finkeldey cell were observed in germinal center area and interfollicular area. (C,D) (H\&E); the morphology of multinucleated giant cells showed some variation, but the nuclei with a single distinct nucleolus were arranged in a grape-like cluster. (E) (CD21); the cytoplasm of multinucleated giant cells was positive for CD21. The cytoplasmic border was indistinct with lymphocytes entrapment. (F) (CXCL13); CXCL13 was positive in the cytoplasm of multinucleated giant cells. (G) (CD43) and (H) (CD20); small lymphocytes entrapped in the cytoplasm of multinucleated giant cells are negative for CD43 and positive for CD20. 


\section{Discussion}

In this study, we present detailed clinical data and pathological findings of 38 histologically well-defined HV-UCD cases. This is a unique study considering the fact that exclusive reports on HV-UCD are scarce in the existing literature and as such detailed evaluation of multiple cases of HV-UCD will add immensely to the current knowledge of this entity.

\subsection{Clinical Characteristics}

Data on age, sex, and symptoms were similar to those in the previous reports [3,7-10]. As discussed earlier, HV-UCD has been thought to occur predominantly in the mediastinal region, but our study revealed that HV-UCD most common involvement site was in the abdominal cavity. Given the advances in imaging modalities [12], the results of the present study may be closer to the actual lesion distribution of HV-UCD.

While malignant tumors (rectal cancer and uterine cancer), benign tumors (uterine leiomyoma, ovarian benign serous tumor, and mature teratoma of the mediastinum), and inflammatory diseases (ascending colon diverticulitis and ischemic enteritis) were present in nine patients, the relationship between these diseases and HV-UCD has been unclear. In severe infections and autoimmune diseases, the adjacent lymph nodes may show reactions such as follicular hyperplasia, hypervascularization, and plasma cell proliferation in the enlarged interfollicular area. However, the histological features of HV-UCD, such as hyalinization of the blood vessels and atrophy of the germinal center, are uncommon in these diseases, so histological differentiation is not considered to be a problem. The patients included in this study did not have any underlying disease that could exhibit histology similar to HV-UCD.

One of our patients had PNP and BO in association with $\mathrm{CD}$. A previous report has shown that $\mathrm{CD}$ is one of the most common causes of tumor-associated pemphigus, along with non-Hodgkin's lymphoma and other hematologic tumors [13,14]. BO is a serious manifestation of PNP and is one of the leading causes of mortality. Although the frequency varies among reports, it has been reported that about $30 \%$ of PNP is associated with BO $[15,16]$, with a higher frequency in children and adolescents with CD. In one report, the frequency of bronchiolitis obliterans was $93 \%$ in a series of 28 patients with PNP, which included 15 children and adolescents with CD [17]. Since autoantibodies produced by tumor cells are responsible for the pathogenesis of mucocutaneous lesions, removal of solid tumors and remission of hematologic tumors by chemotherapy are critical for improvement of PNP [18]. Complete resection of localized Castleman's disease may result in significant improvement or complete remission of the condition [19]. However, it takes several years after surgery to achieve remission, and during that time, serious complications such as respiratory failure can occur.

In this study, four cases of subcutaneous masses, which are considered rare, were also included [20]. One of this was a mass arising in the kidney, which is an extremely rare location for HV-UCD lesions [21]. Other unusual sites such as the orbits, nasopharynx, lungs, and spleen have also been reported in literature [22-25]. Thus, it is important to keep in mind that these unusual sites might also be involved, while making a diagnosis of HV-UCD.

There have been several reports of ${ }^{18} \mathrm{~F}-\mathrm{FDG}$ avid UCD lesions [3,4,26-29]. In these reports, FDG uptake was moderately increased in UCD, and SUVs were generally less than those observed in lymphoma. Our results were also consistent with this.

\subsection{Histological Characteristics}

HV-UCD is preferably diagnosed by excisional biopsy of the enlarged lymph nodes. Although there are several diseases that show CD-like histopathological features such as unusual morphological variants of follicular lymphoma, angioimmunoblastic T-cell lymphoma, these usually present with generalized lymphadenopathy and are rarely confused with UCD [11]. 
The finding of altered follicular structure with expanded mantle zone, as shown in Figure 2, may also be seen as a progressive transformation of germinal centers. In the present study, calcification was found in $23.7 \%$ of lesions. Various patterns of calcification have been reported within the lesion in past reports [3,30-33]. Calcification and extensive hyalinization may indicate that the lesion is indolent.

In this study, multinucleated giant cells resembling Warthin-Finkeldey cells were observed in the germinal center or interfollicular area in nine cases. Although WarthinFinkeldey cells are commonly seen in Kimura disease, a rare chronic inflammatory disease with unclear etiology, these are not unique to Kimura disease and are also observed in measles and a variety of reactive or neoplastic lymphoid conditions. In the present study, these multinucleated giant cells were positive for the follicular dendritic cell (FDC) markers such as CD21 and CXCL13, and were considered to be identical to those referred to as dysplastic FDCs in previous reports [34-38]. It has been reported that FDC sarcoma may occur in lymph nodes in the same region subsequently to UCD $[37,38]$, suggesting that dysplastic FDCs may be a primary driver of UCD pathogenesis.

\subsection{Future Prospects}

The etiology of HV-UCD has been unclear since the disease was first reported over 60 years ago. Although the lineage of cells responsible for the pathogenesis of UCD has not been identified, several studies have hypothesized that a neoplastic stromal cell population may be the precursor of UCD [39-44]. Recently, Li et al. found recurrent PDGFRB N666S mutations in UCD cases, and they also investigated the cell of origin using BaseScope, a mutation-specific RNA in situ hybridization assay. Their results suggested that the PDGFRB N666S mutations were confined to non-hematopoietic stromal cells in UCD, and it is likely that they play an important role in UCD pathogenesis [45].

With this latest body of evidence, we have a better understanding of the pathogenesis of HV-UCD. However, owing to the rarity of the disease, it is necessary to accumulate further evidence with a focus on genetic analysis in the future.

\section{Conclusions}

In conclusion, our study provides up-to-date clinical and pathological findings of patients with HV-UCD. The detailed clinical information presented in this paper is more plausible than previously thought and is useful for accurate diagnosis and understanding of the disease. Comprehensive genetic analysis of histologically well-defined HV-UCD patients is required as a next step in this area of study to clarify the pathogenesis of the disease.

Author Contributions: Conceptualization, M.F.N. and Y.S.; methodology, M.F.N. and Y.S., formal analysis, M.F.N.; investigation, M.F.N.; resources, Y.S.; data curation, M.F.N., A.N., Y.M., and K.M.; writing - original draft preparation, M.F.N.; writing - review and editing, Y.N. and Y.S.; supervision, Y.S. and T.Y.; funding acquisition, Y.S. All authors have read and agreed to the published version of the manuscript.

Funding: This research was funded by a Grant-in-Aid for Scientific Research (C) (JSPS KAKENHI Grant Number JP 20K07407), from the Japan Society for the Promotion of Science, and Grant for Intractable Disease; IgG4-related disease (Grant Number 20FC1040) and Castleman disease (Grant Number 20FC1014), from the Ministry of Health, Labor and Welfare in Japan.

Institutional Review Board Statement: The study was conducted according to the guidelines of the Declaration of Helsinki, and approved by the Institutional Review Board of Okayama University (IRB approval number: 2007-033, date of approval: 20th November 2020).

Informed Consent Statement: We used opt-out to obtain consent from all the patients involved in this study.

Data Availability Statement: Not applicable.

Conflicts of Interest: The authors declare no conflict of interest. 


\section{References}

1. Keller, A.R.; Hochholzer, L.; Castleman, B. Hyaline-vascular and plasma-cell types of giant lymph node hyperplasia of the mediastinum and other locations. Cancer 1972, 29, 670-683. [CrossRef]

2. Cronin, D.M.; Warnke, R.A. Castleman disease: An update on classification and the spectrum of associated lesions. Adv. Anat. Pathol. 2009, 16, 236-246. [CrossRef] [PubMed]

3. Hill, A.J.; Tirumani, S.H.; Rosenthal, M.H.; Shinagare, A.B.; Carrasco, R.D.; Munshi, N.C.; Ramaiya, N.H.; Howard, S.A. Multimodality imaging and clinical features in Castleman disease: Single institute experience in 30 patients. Br. J. Radiol. 2015, 88, 20140670. [CrossRef] [PubMed]

4. Yu, L.; Tu, M.; Cortes, J.; Xu-Monette, Z.Y.; Miranda, R.N.; Zhang, J.; Orlowski, R.Z.; Neelapu, S.; Boddu, P.C.; Akosile, M.A.; et al. Clinical and pathological characteristics of HIV- and HHV-8-negative Castleman disease. Blood 2017, 129, 1658-1668. [CrossRef] [PubMed]

5. Castleman, B. CASE records of the Massachusetts General Hospital Weekly Clinicopathological Exercises: Case 40011. N. Engl. J. Med. 1954, 250, 26-30. [CrossRef]

6. Castleman, B.; Iverson, L.; Menendez, V.P. Localized mediastinal lymphnode hyperplasia resembling thymoma. Cancer 1956, 9 , 822-830. [CrossRef]

7. Dispenzieri, A.; Armitage, J.O.; Loe, M.J.; Geyer, S.M.; Allred, J.; Camoriano, J.K.; Menke, D.M.; Weisenburger, D.D.; Ristow, K.; Dogan, A.; et al. The clinical spectrum of Castleman's disease. Am. J. Hematol. 2012, 87, 997-1002. [CrossRef]

8. Talat, N.; Belgaumkar, A.P.; Schulte, K.M. Surgery in Castleman's disease: A systematic review of 404 published cases. Ann. Surg. 2012, 255, 677-684. [CrossRef] [PubMed]

9. Luo, J.M.; Li, S.; Huang, H.; Cao, J.; Xu, K.; Bi, Y.L.; Feng, R.E.; Huang, C.; Qin, Y.Z.; Xu, Z.J.; et al. Clinical spectrum of intrathoracic Castleman disease: A retrospective analysis of 48 cases in a single Chinese hospital. BMC Pulm. Med. 2015, 15, 34 . [CrossRef]

10. Dong, Y.; Na, J.; Lv, J.; Wang, R.; Chen, X.; Li, N.; Ren, H. Clinical and laboratory characterization of a large cohort of patients with Castleman disease retrospectively collected from a single center. Leuk. Lymphoma 2009, 50, 1308-1317. [CrossRef] [PubMed]

11. Van Rhee, F.; Oksenhendler, E.; Srkalovic, G.; Voorhees, P.; Lim, M.; Dispenzieri, A.; Ide, M.; Parente, S.; Schey, S.; Streetly, M.; et al. International evidence-based consensus diagnostic and treatment guidelines for unicentric Castleman disease. Blood Adv. 2020, 4, 6039-6050. [CrossRef] [PubMed]

12. Han, E.J.; Jung, S.E.; Park, G.; Choi, B.O.; Jeon, Y.W.; Min, G.J.; Cho, S.G. FDG PET/CT Findings of Castleman Disease Assessed by Histologic Subtypes and Compared with Laboratory Findings. Diagnostics 2020, 10, 998. [CrossRef] [PubMed]

13. Lehman, V.T.; Barrick, B.J.; Pittelkow, M.R.; Peller, P.J.; Camilleri, M.J.; Lehman, J.S. Diagnostic imaging in paraneoplastic autoimmune multiorgan syndrome: Retrospective single site study and literature review of 225 patients. Int. J. Dermatol. 2015, 54, 424-437. [CrossRef] [PubMed]

14. Mimouni, D.; Anhalt, G.J.; Lazarova, Z.; Aho, S.; Kazerounian, S.; Kouba, D.J.; Mascaro, J.M., Jr.; Nousari, H.C. Paraneoplastic pemphigus in children and adolescents. Br. J. Dermatol. 2002, 147, 725-732. [CrossRef] [PubMed]

15. Anhalt, G.J. Paraneoplastic pemphigus. J. Investig. Dermatol. Symp. Proc. 2004, 9, 29-33. [CrossRef] [PubMed]

16. Lane, J.E.; Woody, C.; Davis, L.S.; Guill, M.F.; Jerath, R.S. Paraneoplastic autoimmune multiorgan syndrome (paraneoplastic pemphigus) in a child: Case report and review of the literature. Pediatrics 2004, 114, e513-e516. [CrossRef] [PubMed]

17. Nikolskaia, O.V.; Nousari, C.H.; Anhalt, G.J. Paraneoplastic pemphigus in association with Castleman's disease. Br. J. Dermatol. 2003, 149, 1143-1151. [CrossRef] [PubMed]

18. Wang, L.; Bu, D.; Yang, Y.; Chen, X.; Zhu, X. Castleman's tumours and production of autoantibody in paraneoplastic pemphigus. Lancet 2004, 363, 525-531. [CrossRef]

19. Plewig, G.; Jansen, T. Castleman tumor, lichen ruber and pemphigus vulgaris: Paraneoplastic association of immunologic diseases? Hautarzt 1991, 42, 727.

20. Naghashpour, M.; Cualing, H.D.; Szabunio, M.; Bui, M.M. Hyaline-vascular castleman disease: A rare cause of solitary subcutaneous soft tissue mass. Am. J. Dermatopathol. 2010, 32, 293-297. [CrossRef] [PubMed]

21. Mah, N.A.; Peretsman, S.J.; Teigland, C.M.; Banks, P.M. Castleman disease of the hyaline-vascular type confined to the kidney. Am. J. Clin. Pathol. 2007, 127, 465-468. [CrossRef]

22. Kang, D.; Lee, J.; Lee, H.; Baek, S. Unicentric Castleman's disease in the orbit: A case report. Indian J. Ophthalmol. 2015, 63, 555-557. [CrossRef] [PubMed]

23. Tsai, M.H.; Pai, H.H.; Yen, P.T.; Huang, T.S.; Ho, Y.S. Nasopharyngeal Castleman's disease. J. Formos. Med. Assoc. 1996, 95, 877-880. [PubMed]

24. Rawashdeh, B.; Meyer, M.; Yimin, D.; Anthony, C.; Nguyn, D.; Moslemi, M.; Golestani, S.; Richard, S.; Kim, S. Unicentric Castleman's disease presenting as a pulmonary mass: A diagnostic dilemma. Am. J. Case Rep. 2015, 16, 259-261. [CrossRef] [PubMed]

25. Lee, H.J.; Jeon, H.J.; Park, S.G.; Park, C.Y. Castleman's disease of the spleen. World J. Gastroenterol. 2015, 21, 1675-1679. [CrossRef] [PubMed]

26. Lee, E.S.; Paeng, J.C.; Park, C.M.; Chang, W.; Lee, W.W.; Kang, K.W.; Chung, J.K.; Lee, D.S. Metabolic characteristics of Castleman disease on 18F-FDG PET in relation to clinical implication. Clin. Nucl. Med. 2013, 38, 339-342. [CrossRef] [PubMed] 
27. Li, Y.M.; Liu, P.H.; Zhang, Y.H.; Xia, H.S.; Li, L.L.; Qu, Y.M.; Wu, Y.; Han, S.Y.; Liao, G.Q.; Pu, Y.D. Radiotherapy of unicentric mediastinal Castleman's disease. Chin. J. Cancer 2011, 30, 351-356. [CrossRef]

28. Toita, N.; Kawamura, N.; Hatano, N.; Takezaki, S.; Ohkura, Y.; Yamada, M.; Okano, M.; Okada, T.; Sasaki, F.; Kubota, K.C.; et al. A 5-year-old boy with unicentric Castleman disease affecting the mesentery: Utility of serum IL-6 level and (18)F-FDG PET for diagnosis. J. Pediatr. Hematol. Oncol. 2009, 31, 693-695. [CrossRef] [PubMed]

29. Murphy, S.P.; Nathan, M.A.; Karwal, M.W. FDG-PET appearance of pelvic Castleman's disease. J. Nucl. Med. 1997, 38, 1211-1212. [PubMed]

30. Zarate-Osorno, A.; Medeiros, L.J.; Danon, A.D.; Neiman, R.S. Hodgkin's disease with coexistent Castleman-like histologic features. A report of three cases. Arch. Pathol. Lab. Med. 1994, 118, 270-274.

31. McAdams, H.P.; Rosado-de-Christenson, M.; Fishback, N.F.; Templeton, P.A. Castleman disease of the thorax: Radiologic features with clinical and histopathologic correlation. Radiology 1998, 209, 221-228. [CrossRef] [PubMed]

32. Kwon, S.; Lee, K.S.; Ahn, S.; Song, I.; Kim, T.S. Thoracic Castleman disease: Computed tomography and clinical findings. J. Comput. Assist. Tomogr. 2013, 37, 1-8. [CrossRef] [PubMed]

33. Ko, S.F.; Wan, Y.L.; Ng, S.H.; Lin, J.W.; Hsieh, M.J.; Fang, F.M.; Lee, T.Y.; Chen, W.J. Imaging features of atypical thoracic Castleman disease. Clin. Imaging 2004, 28, 280-285. [CrossRef]

34. Menke, D.M.; Tiemann, M.; Camoriano, J.K.; Chang, S.F.; Madan, A.; Chow, M.; Habermann, T.M.; Parwaresch, R. Diagnosis of Castleman's disease by identification of an immunophenotypically aberrant population of mantle zone B lymphocytes in paraffin-embedded lymph node biopsies. Am. J. Clin. Pathol. 1996, 105, 268-276. [CrossRef] [PubMed]

35. Wang, H.W.; Pittaluga, S.; Jaffe, E.S. Multicentric Castleman disease: Where are we now? Semin. Diagn. Pathol. 2016, 33, $294-306$. [CrossRef] [PubMed]

36. Medina, E.A.; Fuehrer, N.E.; Miller, F.R.; Kinney, M.C.; Higgins, R.A. Dysplastic follicular dendritic cells in hyaline-vascular Castleman disease: A rare occurrence creating diagnostic difficulty. Pathol. Int. 2016, 66, 535-539. [CrossRef]

37. Sun, X.; Chang, K.C.; Abruzzo, L.V.; Lai, R.; Younes, A.; Jones, D. Epidermal growth factor receptor expression in follicular dendritic cells: A shared feature of follicular dendritic cell sarcoma and Castleman's disease. Hum. Pathol. 2003, 34, 835-840. [CrossRef]

38. Vermi, W.; Lonardi, S.; Bosisio, D.; Uguccioni, M.; Danelon, G.; Pileri, S.; Fletcher, C.; Sozzani, S.; Zorzi, F.; Arrigoni, G.; et al. Identification of CXCL13 as a new marker for follicular dendritic cell sarcoma. J. Pathol. 2008, 216, 356-364. [CrossRef] [PubMed]

39. Wu, D.; Lim, M.S.; Jaffe, E.S. Pathology of Castleman Disease. Hematol. Oncol. Clin. 2018, 32, 37-52. [CrossRef]

40. Fajgenbaum, D.C.; Shilling, D. Castleman Disease Pathogenesis. Hematol. Oncol. Clin. 2018, 32, 11-21. [CrossRef] [PubMed]

41. Chang, K.C.; Wang, Y.C.; Hung, L.Y.; Huang, W.T.; Tsou, J.H.; Jones, D.M.; Song, H.L.; Yeh, Y.M.; Kao, L.Y.; Medeiros, L.J. Monoclonality and cytogenetic abnormalities in hyaline vascular Castleman disease. Mod. Pathol. 2014, 27, 823-831. [CrossRef] [PubMed]

42. Andersen, E.F.; Paxton, C.N.; O’Malley, D.P.; Louissaint, A., Jr.; Hornick, J.L.; Griffin, G.K.; Fedoriw, Y.; Kim, Y.S.; Weiss, L.M.; Perkins, S.L.; et al. Genomic analysis of follicular dendritic cell sarcoma by molecular inversion probe array reveals tumor suppressor-driven biology. Mod. Pathol. 2017, 30, 1321-1334. [CrossRef] [PubMed]

43. Pauwels, P.; Dal Cin, P.; Vlasveld, L.T.; Aleva, R.M.; van Erp, W.F.; Jones, D. A chromosomal abnormality in hyaline vascular Castleman's disease: Evidence for clonal proliferation of dysplastic stromal cells. Am. J. Surg. Pathol. 2000, 24, 882-888. [CrossRef]

44. Cokelaere, K.; Debiec-Rychter, M.; De Wolf-Peeters, C.; Hagemeijer, A.; Sciot, R. Hyaline vascular Castleman's disease with HMGIC rearrangement in follicular dendritic cells: Molecular evidence of mesenchymal tumorigenesis. Am. J. Surg. Pathol. 2002, 26, 662-669. [CrossRef] [PubMed]

45. Li, Z.; Lan, X.; Li, C.; Zhang, Y.; Wang, Y.; Xue, W.; Lu, L.; Jin, M.; Zhou, Z.; Wang, X.; et al. Recurrent PDGFRB mutations in unicentric Castleman disease. Leukemia 2019, 33, 1035-1038. [CrossRef] [PubMed] 